\title{
Evaluating Self-Efficacy Expected of Polytechnic Engineering Students as a Measure of Employability
}

\author{
Oguche Innocent Ojonugwa (Corresponding author) \\ Faculty of Educational Studies, Universiti Putra Malaysia, Malaysia \\ E-mail: innojoguche@gmail.com \\ Ramlah Hamzah \\ Faculty of Educational Studies, Universiti Putra Malaysia, Malaysia \\ E-mail: ramlah@educ.upm.edu.my \\ AB Rahim Bakar \\ Faculty of Educational Studies, Universiti Putra Malaysia, Malaysia \\ Abdullah Mat Rashid. \\ Faculty of Educational Studies, Universiti Putra Malaysia, Malaysia
}

Received: 08-05- 2015

doi:10.7575/aiac.ijels.v.3n.3p.24
Accepted: 14-06-2015

Published: 31-07-2015

\begin{abstract}
In the face of increasing unemployment partly due to decreasing employability skills of Nigeria polytechnic students, many graduates of Nigeria polytechnic have a dwindle self-efficacy. 420 HND 2 polytechnic engineering students in north central states of Nigeria were surveyed. Data were collected using questionnaire consisting of 4 Likert-type statements. Student's self-efficacy was measured by asking students to rate themselves from 1 ("No confidence") to 4 ("Complete confidence").The self-efficacy of engineering students in Nigeria polytechnic were examined using mean and standard deviation. The mean score for Self-appraisal, Occupational Information, Goal selection, Planning and Problem solving are as follow (3.32), (2.97), (3.28), (3.082) and (3.012) respectively with self-appraisal scoring higher than the others. These findings enhance our understanding of the importance of self-efficacy in the development of employability skills of polytechnic engineering students in Nigeria, more importantly self-appraisal had the highest mean score. The practical implication is that the teaching style will have to shift from being teacher-centred leaning to student-centred learning in order to address and accommodate the need of student's self-efficacy.
\end{abstract}

Key words: Self-efficacy; Employability; Employability skills; Nigerian polytechnics; Engineering students

\section{Introduction}

Self-efficacy is the beliefs about ability to function and accomplish specific tasks without assistance from others, to make decisions and belief in them, in others words it is the confidence to achieve goals through personal efforts, persistence in the face of challenges and coming out with original solutions (Bezuidenhout, 2011). Self-efficacy is what an individual believes he or she can accomplish using his or her skills under certain circumstances (Yang \& Lu, 2007).

Self-efficacy was developed by Albert Bandura, his emphasis was on behavioral change, His proposal was that personal, and environmental elements influences one another to determine motivation and behavior (Crothers, Hughes, \& Morine, 2008). More simply, (Redmond, 2013) self-efficacy can be said to be the believe of an individual to achieve using his or her ability under certain situation. Social Cognitive Theory (SCT) is known as social cognitive approach to personality, it involves a mutual relationship of the social environment with the person's conscious cognition. (Denler, Wolters, \& Benzon, 2014) noted that classroom learning is shaped by factor within the academic environment, especially the reinforcement experienced by oneself. The further stressed that learning is affected by students own thoughts and self-beliefs and the interaction of the classroom context. It implies that a person consciously select construct actions and decides the final behavior. For this purpose they can access concrete events as well as symbolic representation of activities, goals and future occurrences

Another assumption within SCT is that people have the ability to influence their own behaviour and the environment with particular goals in focus (Baneck, 2012). For every learning the learner has attributed on himself a personal agency. Simply put, he determine the way he should learn. There are four core features of personal agency. They include:

Intentionality: Intentionality refers to representation of the future course of action which means the learner projecting into the future in doing something with the learning acquired, (futuristic projection). 
Forethought: Learners use forethought to envision the future, identify desired outcomes and generate plan of action. Planning is a dimension of agency, this is the temporal extension of the personal agency in future. It leads to anticipatory consequences.

Self-reactiveness: This refers to one's reaction to his behaviour and being able to manipulate it. There are dual focuses to self-reactiveness known as self-regulation and self-reinforcement (Zimmerman \& Schunk, 2001). Self-regulation refers to the ability of an individual to actualize goal to give shape to appropriate courses of action and to regulate their execution, while self-reinforcement refers to self-produced consequences of an action. A person possesses an internal standard of feedback for one's own performance.

According Brian, (2014), people behave in the way they execute their initial beliefs; thus, self-efficacy theory functions as a self-fulfilling prophecy. It has influence over people's ability to learn, their motivation and their performance, as people will often attempt to learn and perform only those task for which they believe they will be successful in it (Lunenburg 2011). Self-efficacy beliefs can influence factors such as motivation and commitment levels as well as an individual's willingness to take on difficult tasks. From (Yorke \& Knight, 2007) perspective, students should have the confidence in themselves that they can make a difference. Students need to believe that by working hard they are able to enhance their own abilities and potential outcomes (Holker, 2010). People with high-levels self-efficacy in most cases are likely to succeed in tasks and goals, while people with low self-efficacy usually submit to self-doubt at the end, limiting their goal achievement. Hence, self-efficacy beliefs influence people's behaviors and actions (Cole, Holtgrave, \& Ríos, 1992). Self-efficacy theory is an important dimension of employability(Knight \& Yorke, 2002). It is a tool that helps the individual build confidence for work. Self-efficacy has been also recognized as a useful learning vehicle that can be used in an educational and employability contexts (Lees, 2002). This should be encouraged and nurtured. Students, who have self-efficacy belief in their own ability to produce, organize and undertake tasks will have an effect on their performance. (Knight \& Yorke, 2003) considers that it is not enough to have a range of cognitive, social, emotional and behavioral sub-skills, but that these have to be integrated into the challenges that are faced. Therefore, self-efficacy will play an important role in personal development, which will be significant for graduate's employability.

\section{Self-efficacy and Employability}

Self-efficacy, self-confidence and self-esteem have always been confused for each other. (Pool \& Sewell, 2007b) explained that they provide a crucial link between knowledge, understanding, skills, experience and personal attributes and employability. It is however important to note the differences between the two. Self-esteem is one's ability to attach value to himself unconditionally, It is referring to yourself that you are a human being. It is also the ability of the individual to refer to himself with absolute importance that he is special, unique and precious. It is there all the time, noone can take it away from you, your belief, and your faith. Powers of thought, emotion, speech and movement controls our self-esteem. You can do things positively no matter what you think about yourself, the ability to esteem yourself leads one to self-confidence.

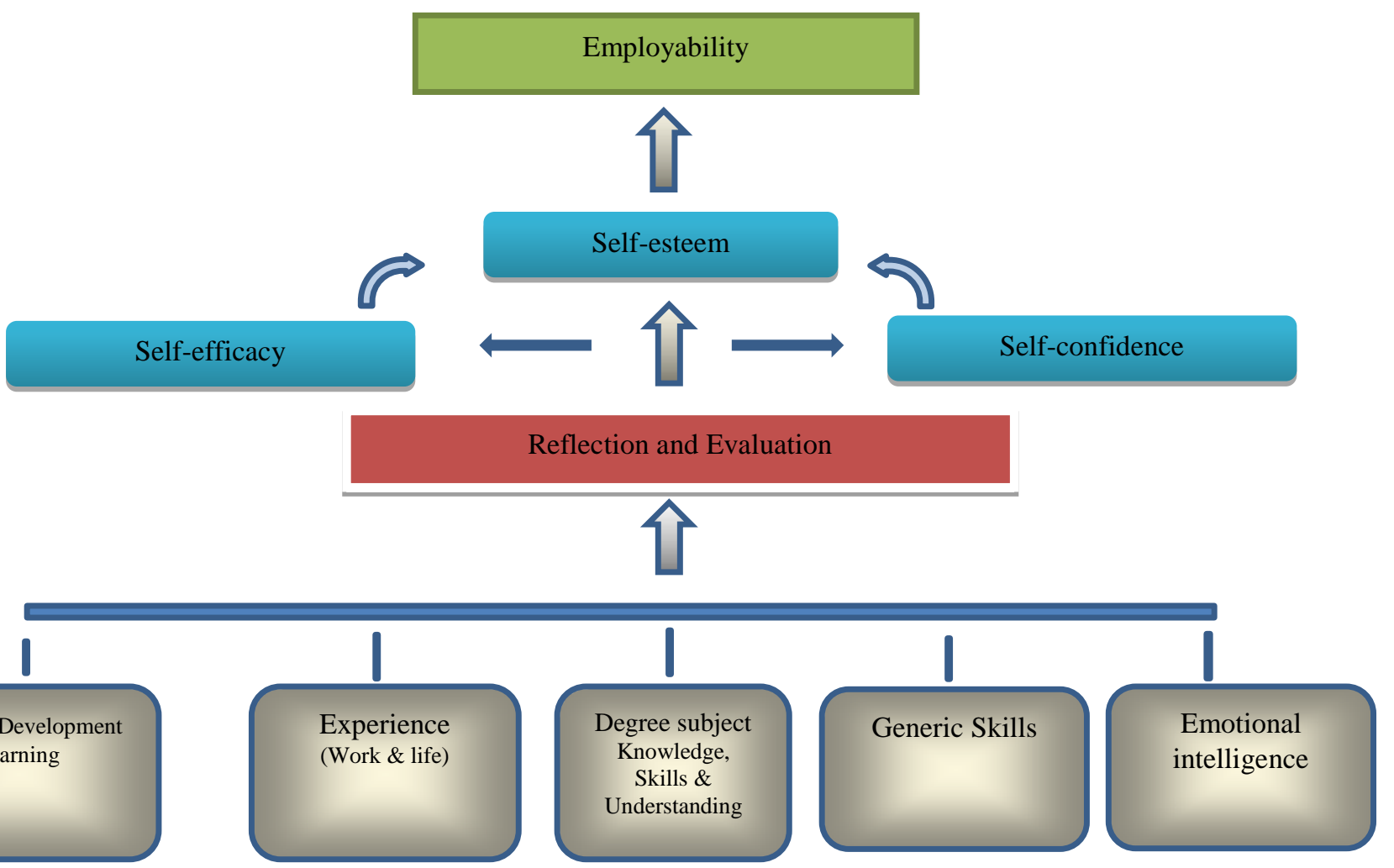

Figure 1. The CareerEDGE model of Graduate Employability 
This model can also be known by the components mnemonics of CareerEDGE, it is valuable in that it can be used to explain the concept of employability to those new to the subject, and to students and their parents as well as appealing to academics. (Pool \& Sewell, 2007) argued that by providing students to access and develop these five components and then reflect on and evaluate such experience, it will result in the development of higher levels of self-efficacy, selfconfidence and self-esteem, this factors of course are known to be very critical in the employment of young graduates (Pool \& Sewell, 2007; Yorke, 2006).

Pool \& Sewell, (2007) also agree that the relevance of this model lies in its simplicity. It can be explained to students or the lecturer and even the parents with ease. The model can also serve future relevance for planning useful curriculum and can demonstrate to the employers the valued role the tertiary institutions play in moulding young graduates for employability. Also it brings out how important the employers of labour and higher institutions can cooperate and contribute to increase qualitative employability. This will be beneficial to all the relevant parties (Nicola Symington, 2012) This study attempts to determine factors influencing employability among polytechnic engineering students in Nigeria. The beliefs this students have in acquiring necessary skills for employment is considered as being important as this will determine their success in life. Bandura, (1995) describes self-efficacy as the "beliefs in one's capabilities to organize and execute the courses of action required to manage prospective situations". Self-efficacy beliefs can influence factors such as self-concepts, skill confidence, general feelings and commitment levels as well as an individual's willingness to take on difficult tasks. In the technical and vocational domain where task may look complex, difficult and demanding, self-efficacy gives confidence to the individual to accomplish such task no matter how complex. Job performance is an important factor to be considered as the ultimate aim of any training is of commensurate or greater output. Bandura, (1977) stressed performance outcomes, or past experiences, as the most important source of self-efficacy. Positive training can influence the employability of an individual and also job performance. If one has performed well at a task previously, he or she is more likely to feel competent and perform well at a similarly associated task (Bandura, 1977).

In addition, an individual's employability assets include their knowledge, skills and attitudes, both the Bandura Selfefficacy and social cognitive theory and the human capital theory. These are main determinants that have been stated to have influenced employability. Linking this to contemporary times investment in human capital, is any action that helps improves an individual's skills and abilities which can lead a reliable employment of the individual improving the wage value in the labor market (International Labour Office, 2010). This is achievable through quality higher education which gives students the confidence and skills needed to succeed in the job labour market. Education helps to foster this belief in students so that they can do and become all they are meant to be in life (United Nations, 2013). The propositions of human capital theory were that the skills that people acquire are a form of capital, which is referred to as human capital. Education is the principal instrument for providing the skills required by the economy and also for improving the overall levels of efficiency, productivity, technological and managerial performance of the labour force (Little, 2002). Education has recently been re-theorised under human capital theory as primarily an economic device seeing individuals as human capital and various economic metaphors such as technology change, innovation, production and education should be used to develop this capital (Akinyemi \& Abiddin, 2013). Existing schools infrastructures should be made relevant to meet the challenge of the time. Excellence in education, no doubt, is a challenge that stands in our way to developing a credible pool of human capital. It is obvious that schools and teachers are succeeding in creating environments from which students derive interest and satisfaction and some excitement from the learning tasks they encounter. The interest orientation formed by the school experience endures and transfers to the workplace (Little, 2002).

(Mantz Yorke \& Knight, 2007) suggest that employability should be considered in terms of the attributes of students in this four areas: subject understanding, of generic skills application, metacognition and efficacy beliefs. It is expected that graduates should possess these attributes ensuring they have the capability of being effective in the workplace benefiting themselves, their employer and the wider economy. This is why many countries include the delivery of skills in the regular school curriculum. Employers of labour are looking for graduates who can articulate and provide evidence for these skills, achievements and attributes, drawing on both academic and extra-curricular experience. Skills include: self-management, team working, business and customer awareness, problem solving, communication and literacy, application of numeracy, and application of information technology.

\section{Objectives}

The main objective of the study was to examine the self-efficacy attributes of engineering students in Nigeria polytechnic.

\subsection{Research Question}

What are the self-efficacy attributes of engineering students in Nigeria polytechnic.

\section{Methodology}

This study is a quantitative survey design. Final semester HND 2 students of mechanical, electrical, civil, and computer engineering of federal and state polytechnics in Nigeria were surveyed. The study was conducted in north central geopolitical zone of Nigeria. To assess students' self-efficacy, it was operationalized into 4 measures. Items for selfefficacy were adapted from the instrument used by Gregory Reddan (2009) Improving Exercise Science students' selfefficacy in making positive career decisions. The measures are self-appraisal, occupational information, goal selection, planning and problem solving, each of the measures consist 5 items required for assessing Self-efficacy. The 
questionnaire consists of 4 Likert-type statements. Student's self-efficacy will be measured by asking students to react to these items. Each item related to the self-concept and will be rated by respondents from 1 ("No confidence") to 4 (“Complete confidence").

Statistical analysis was performed using SPSS software (version 22). Fifty respondents from a Federal Polytechnic in Nigeria were drawn from students of Four Engineering Departments (Mechanical, Electrical, Civil, and Computer) for the reliability test. The results of the analysis shows that the entire items for self-efficacy met the recommended Cronbach alpha, indicating that all the items measured their construct. The Cronbach alpha was 0.900 which is greater than 0.7. The results of the reliability test conformed with the suggestion in Pallant (2010) and Nunnally (1978). Both authors suggested a minimum level of 0.7 Cronbach alpha values for a large items scale.

\section{Results and Discussions}

The total number of students surveyed consist of 420 respondents out of which about $6 \%$ are female while about $94 \%$ are male. According to their marital status about, $06 \%$ of the respondents are married, while about $094 \%$ are single. In term of age of the respondents, the age distribution were divided into four groups, and ages 26 to 35 is the age group with the largest participants which comprised of $50.95 \%$ of the sample population, while about $47.62 \%$ of respondents are within the age 16-25. The analysis further shows that those within the age 36-45 are about $0.95 \%$, while the participants within the age 46-55 are about $.48 \%$. This shows that majority of the participants are within the age 26-35 years, followed by those with age bracket $16-25$. Those within the age $36-45$ and $46-55$ are about $0.95 \%$ and $0.48 \%$ of the total sampled population respectively.

From the data respondents were distributed into their field of study, about $43.3 \%$ of the participants were studying for Mechanical Engineering, 38.1\% are into Electrical Engineering, while about $12 \%$ are studying for Civil Engineering, and $6.2 \%$ are students of Computer Engineering. Another characteristics of respondents is institutions of study and this shows that about $34 \%$ of the participants are students of Federal Polytechnic Idah, $28 \%$ study at Federal Polytechnic Bida, $18.3 \%$ at Federal Polytechnic Nasarawa, 11.9\% of the participants are students of Federal Polytechnic Offa and $06 \%$ of the participants are students of Benue State Polytechnic Benue.

Table 1. Demographic Characteristics of Respondents

\begin{tabular}{ccc}
\hline Profile & Frequency & Percentage (\%) \\
\hline Gender & & 94 \\
1. Male & 398 & 06 \\
2. Female & 25 & \\
& & 94 \\
Marital Status & & 06 \\
1.Single & 395 & \\
2. Married & 25 & \\
& & 47.62 \\
Age & & 50.95 \\
1. 16-25 & & 0.95 \\
2. $26-35$ & 200 & 0.48 \\
$3.36-45$ & 214 & 04 \\
$4.46-55$ & 02 &
\end{tabular}

\section{Field of Study}

1. Mechanical Engineering $\quad 204 \quad 28.9$

2. Electrical Engineering $\quad 50 \quad 7.1$

$\begin{array}{lll}\text { 3. Civil Engineering } & 210 & 29.8\end{array}$

4. Computer Engineering $134 \quad 19.0$

\section{Polytechnic of Study}

1. Federal Polytechnic Idah $\quad 143 \quad 34$

2. Federal Polytechnic Bida $\quad 121 \quad 28$

$\begin{array}{lll}3 \text { Federal Polytechnic Nasarawa } & 77 & 18.3\end{array}$

$\begin{array}{lll}\text { 4. Federal Polytechnic Offa } & 50 & 11.9\end{array}$

$\begin{array}{lll}\text { 5. Benue State Polytechnic Benue } & 29 & 06.9\end{array}$ 


\subsection{Ratings on Self-efficacy}

The data presented in table 2 below under self-appraisal revealed that "Can express the type of lifestyle you would like to live" scored the highest mean of $(\mathrm{M}=3.44, \mathrm{~S} . \mathrm{D}=0.654)$ Followed by "decide what you want in an occupation" with a mean score of $(\mathrm{M}=3.32$, $\mathrm{S} . \mathrm{D}=0.704)$ while "i can accurately assess my abilities" and "determine what your ideal job would be" scored the lowest mean of $(M=3.27,3.27, \mathrm{~S} . \mathrm{D}=0.65,1.147)$ respectively.

Under occupational information "Can discover for myself information about occupations of interest" score the highest mean of $(\mathrm{M}=3.22$, S.D $=0.71)$ followed by "talk with a person already employed in the field you are interested in" with a mean of $(M=3.08$, S.D $=0.749)$. "Find out the employment trends for an occupation over the next 10 years" and "Find out per week average earnings of employees in an occupation" scored the lowest mean of $(\mathrm{M}=2.8,2.8, \mathrm{~S} . \mathrm{D}=0.747$, $0.74)$ respectively.

Out of the five items under goal selection "Choose a major field of study that best suits your interests" scored a mean of $(\mathrm{M}=3.35 \mathrm{~S} . \mathrm{D}=0.698)$, "Select a career that will fit into the lifestyle you would preferred" closely followed with a mean score of $(\mathrm{M}=3.34,0.664)$. "Choose a diploma program from a list of potential programs you have dimed fit" and "select one occupation from a list of potential occupations you are considering" had their mean score to be $(\mathrm{M}=3.2,3.2$ S.D $=0.677,0.59)$

It can be seen from the data in Table 3 under planning that "Organise steps needed to successfully complete your chosen diploma program" had the highest mean score of $(\mathrm{M}=3.15, \mathrm{~S} . \mathrm{D}=0.695)$ followed by "Draw up a plan of goals you wish to achieve for the next 5 years" with a mean score of $(\mathrm{M}=3.13$, S.D=0.748). "Successfully handle work interview procedures" scored the lowest mean score of $(\mathrm{M}=2.99$, S.D $=0.686)$

The last group under self-efficacy is Problem solving, "In a situation of academic trouble in an aspect of your chosen diploma you can determine steps to taken" had the highest score of $(\mathrm{M}=3.06, \mathrm{~S} . \mathrm{D}=0.681)$ followed by "Identify alternative diploma programs if you are unable to get your first choice" with a mean score of $(M=3.05$, S.D $=0.7)$. While "Select a different diploma if you did not like the first one you entered for" had the lowest mean score of $(\mathrm{M}=2.9$, $\mathrm{S} . \mathrm{D}=0.694)$.

Looking at the total mean score of each group it is indicated that the overall mean have an average mean score total of above the moderate level of 2.00. Self-appraisal scored the highest total mean of 3.32 while occupational information scored the lowest mean of 2.97 .

Table 2. Distribution of respondents answer to related items to Self-efficacy $(n=420)$

\begin{tabular}{|c|c|c|c|c|c|c|c|}
\hline Variable & Items & $\begin{array}{l}\text { No } \\
\text { Confidence }\end{array}$ & $\begin{array}{l}\text { Low } \\
\text { confidence }\end{array}$ & $\begin{array}{l}\text { Moderate } \\
\text { Confidence }\end{array}$ & $\begin{array}{l}\text { High } \\
\text { Confidence }\end{array}$ & Mean & SD \\
\hline \multirow{6}{*}{$\begin{array}{l}\text { Self- } \\
\text { appraisal }\end{array}$} & I can accurately assess my abilities & 1 & 8.3 & 53.3 & 37.4 & 3.27 & 0.65 \\
\hline & Determine what your ideal job would be. & 0.5 & 9 & 57.6 & 32.6 & 3.27 & 1.147 \\
\hline & Decide what you want in an occupation & 0.7 & 11.7 & 42.4 & 45.2 & 3.32 & 0.704 \\
\hline & $\begin{array}{l}\text { Undestand what to sacrifice to achieve } \\
\text { your career goals }\end{array}$ & 1 & 11.4 & 44.5 & 43.1 & 3.3 & 0.704 \\
\hline & $\begin{array}{l}\text { Can express the type of lifestyle you } \\
\text { would like to live }\end{array}$ & 0.2 & 8.3 & 39 & 52.4 & 3.44 & 0.654 \\
\hline & Total & & & & & 3.32 & \\
\hline \multirow[t]{6}{*}{$\begin{array}{l}\text { Occupational } \\
\text { Information }\end{array}$} & $\begin{array}{l}\text { Can discover for myself information about } \\
\text { occupations of intereste }\end{array}$ & 2.1 & 10 & 51.2 & 36.7 & 3.22 & 0.71 \\
\hline & $\begin{array}{l}\text { Investigate over the next } 10 \text { years the } \\
\text { employment trends of an occupation }\end{array}$ & 4.5 & 26.4 & 53.8 & 15.2 & 2.8 & 0.747 \\
\hline & $\begin{array}{l}\text { Find out per week average earnings of } \\
\text { employees in an occupation }\end{array}$ & 1.9 & 33.6 & 47.1 & 17.4 & 2.8 & 0.74 \\
\hline & $\begin{array}{l}\text { Talk with a person already employed in } \\
\text { the field you are interested in }\end{array}$ & 2.1 & 17.9 & 49.8 & 30.2 & 3.08 & 0.749 \\
\hline & $\begin{array}{l}\text { Find information about postgraduate } \\
\text { programs }\end{array}$ & 1.4 & 27.4 & 44 & 27.1 & 2.97 & 0.776 \\
\hline & Total & & & & & 2.97 & \\
\hline \multirow[t]{6}{*}{$\begin{array}{l}\text { Goal } \\
\text { selection }\end{array}$} & $\begin{array}{l}\text { Choose a diploma program from a list of } \\
\text { potential programs you have dimed fit. }\end{array}$ & 1.2 & 11.4 & 54 & 33.3 & 3.2 & 0.677 \\
\hline & $\begin{array}{l}\text { Select one occupation from a list of } \\
\text { potential occupations you are considering }\end{array}$ & 0.5 & 7.9 & 62.6 & 29 & 3.2 & 0.59 \\
\hline & $\begin{array}{l}\text { Select a career that will fit into the } \\
\text { lifestyle you would preferred }\end{array}$ & 0.5 & 9.3 & 45.7 & 44.5 & 3.34 & 0.664 \\
\hline & $\begin{array}{l}\text { Decide a career and stick to it whether } \\
\text { right or wrong }\end{array}$ & 1 & 10.2 & 47.9 & 41 & 3.29 & 0.684 \\
\hline & $\begin{array}{l}\text { Choose a major field of study that best } \\
\text { suits your interests }\end{array}$ & 0.5 & 11.4 & 40.5 & 47.6 & 3.35 & 0.698 \\
\hline & Total & & & & & 3.28 & \\
\hline
\end{tabular}


Table 3. Distribution of respondents answer to related items to Self-efficacy $(n=420)$

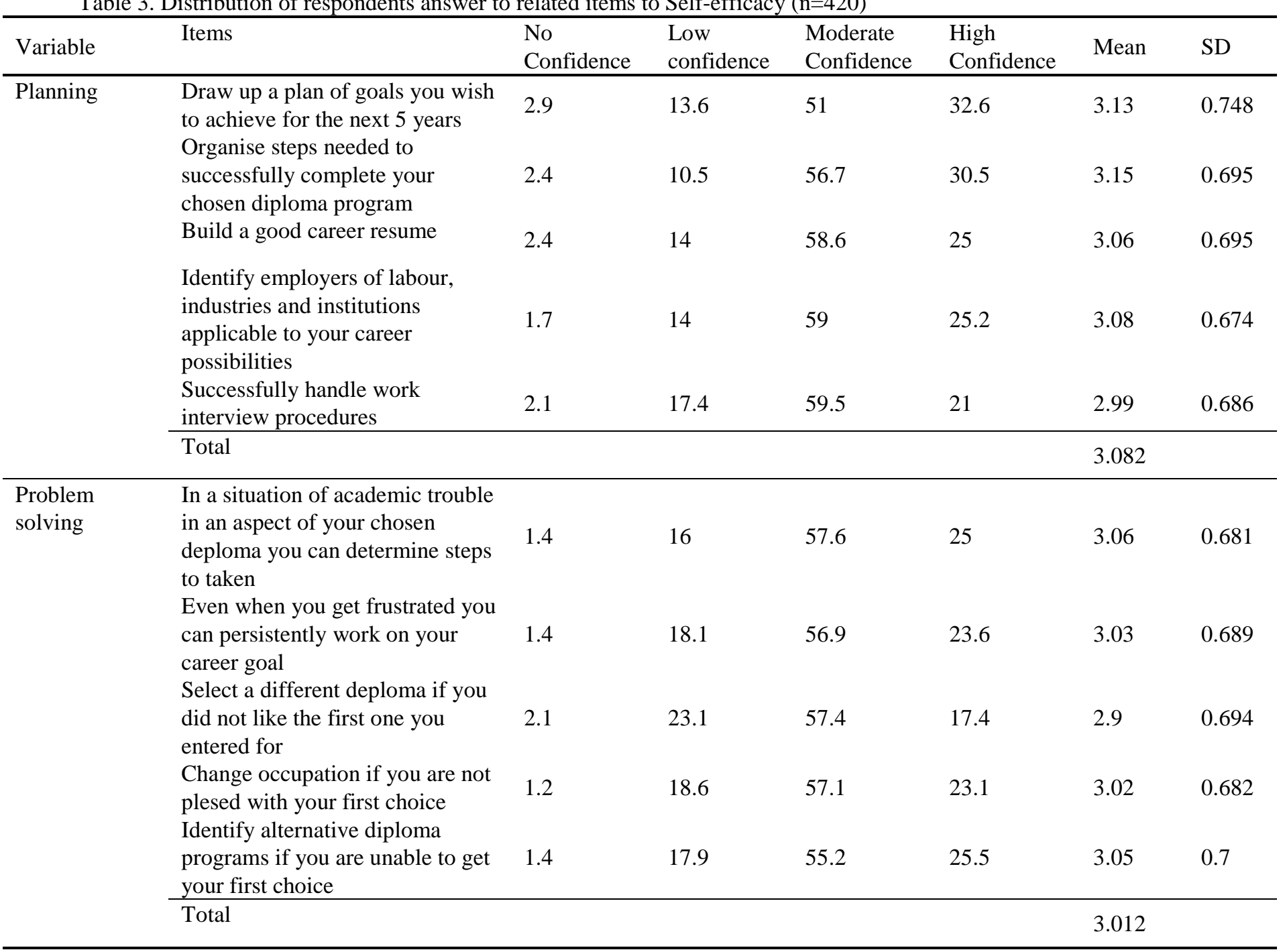

\section{Conclusion and Recommendations}

This study set out to examine the self-efficacy of engineering students in Nigeria polytechnic. Overall, the results indicate that engineering students in Nigeria polytechnics have acquired high level of self-efficacy scoring above average in all constructs that were used to measure self-efficacy. These results are in agreement with those obtained by Reddan, (2009) who findings indicate positive trends in students' perceptions in regards to their believe of self-efficacy. It also agree with O'Donnell \& Media, (2015) who argued that self-efficacy measurements encourage confidence, selfadvocacy and student ownership of learning. Some other important findings from this study indicate that student from Nigerian polytechnics have good ability of goal selection, students indicated that their goal solving ability is also high. Pool \& Sewell, (2007b) argued that self-efficacy skills are known to be very critical in the employment of young graduates.The most striking result to emerge from the data is that self-appraisal scored the highest mean which is in support of Yorke \& Knight, (2007) prospecting that the personal qualities required of students is the confidence that they can make a difference in their career. It imply that, through proper self-appraisal students become more aware of their own self-efficacy beliefs, and the impact that these can have on their employment prospects is enormous. These findings also indicate that there is room for improvement on the self-efficacy of students giving room for better employability skills. The practical implication of this study provides significant benefits not only for the government of Nigeria, but also to the administrators of Nigerian Polytechnics who should ensure that the teaching style should shift from teacher-centred learning to student-centred learning in order to address and accommodate the need of the students self-efficacy.

\section{References}

Akinyemi, G. M., \& Abiddin, N. Z. (2013). Human Capital Developments an Interdisciplinary Approach for Individual, Organization Advancement and Economic Improvement. Asian Social Science, 9(4), 150-157. doi:10.5539/ass.v9n4p150

Bandura, A. (1977a). Self-efficacy: Toward a unifying theory of behavioral change. Psychological Review, 8(2).

Bandura, A. (1977b). Self-efficacy: Toward a unifying theory of behavioral change. Psychological Review. Psychological Review, 84(2). 
Bandura, A. (1995). "Exercise of personal and collective efficacy in changing societies." In Bandura, A. (Ed.) Selfefficacy in Changing Societies. Cambridge: Cambridge University Press.

Baneck, T. M. (2012). Parochial Dissonance: A Grounded Theory of Wisconsin's New North Response to the Employability Skills Gap. CARDINAL STRITCH UNIVERSITY.

Bezuidenhout, M. (2011). The development and evaluation of a measure of graduate employability in the context of the new world of work. University of Pretoria, Pretoria.

Brian Francis Redmond. (2013). Self-Efficacy and Social Cognitive Theories. Retrieved from https://wikispaces.psu.edu/display/PSYCH484/7.+Self-Efficacy+and+Social+Cognitive+Theories

Brian Francis Redmond. (2014). Self-Efficacy and Social Cognitive Theories Skip to end of metadata. Retrieved from https://wikispaces.psu.edu/display/PSYCH484/7.+Self-Efficacy+and+Social+Cognitive+Theories

Cole, G. E., Holtgrave, D. R., \& Ríos, N. M. (1992). Internal and External Factors That Encourage or Discourage Health-Relevant Behaviors, 1-23. $\quad$ Retrieved from http://www.orau.gov/cdcynergy/soc2web/Content/activeinformation/resources/Health_Behavior_Factors.pdf

Crothers, L. M., Hughes, T. L., \& Morine, K. A. (2008). Theory and cases in school-based consultation: A resource for school psychologists, school counselors, special educators, and other mental heath professionals. New York: Routledge Taylor \& Francis Group. Retrieved from http://books.google.com/books?id=vKsXLZkKiyIC

Denler, H., Wolters, C., \& Benzon, M. (2014). Social Cognitive Theory. Retrieved from http://www.education.com/reference/article/social-cognitive-theory/

Holker, T. (2010). Supporting Students to Develop Attitudes to Learning that Strengthen Their Self-Efficacy Beliefs and Employability Credentials, $1-7$.

International Labour Office. (2010). A Skilled Workforce for Strong, Sustainable and Balanced Growth. Retrieved from http://www.oecd.org/g20/topics/employment-and-social-policy/G20-Skills-Strategy.pdf

Knight, P. T., \& Yorke, M. (2002). Employability Through the Curriculum. Tertiary Education and Management, 8(4), 261-276. doi:10.1023/A:1021222629067

Knight, P. T., \& Yorke, M. (2003). Employability and Good Learning in Higher Education. Teaching in Higher Education, 8(1), 3-16. doi:10.1080/1356251032000052294

Lees, D. (2002). Graduate Employability - Literature Review. Retrieved from http://qualityresearchinternational.com/esecttools/esectpubs/leeslitreview.pdf

Little, A. W. (2002). Motivating Learning and the Development of Human Capital. Journal Compare, 33(4), 1-24.

Lunenburg F. (2011). Self-efficacy in the workplace: implications for motivation and performance. International Journal of Management, Business, And Administration,. Journal Volumes/Lunenburg, 14(1). Retrieved from http://www.nationalforum.com/Electronic

Nicola Symington. (2012). Investigating Graduate Employability And Psychological Career Resources. University of Pretoria.

Nunnally, J. C. (1978). Assessment of Reliability. In: Psychometric Theory (2nd ed.). New York: McGraw-Hill Company, Inc.

O’Donnell, G., \& Media, D. (2015). Academic Self-Efficacy Measurement. Global Post.

Pallant Julie. (2010). Journeys in Survey Research: SPSS Survival Manual: A Step by Step Guide to Data Analysis (4th editio.). Open University Press.

Pool, L. D., \& Sewell, P. (2007a). The CareerEDGE model of Graduate Employability. Retrieved from C:IUsers Innocent $\backslash$ DownloadsITWO63-Presentation-by-L-DacrePool.ppt

Pool, L. D., \& Sewell, P. (2007b). The key to employability: developing a practical model of graduate employability. Education + Training, 49(4), 277-289. doi:10.1108/00400910710754435

Reddan, G. (2009). Improving Exercise Science students ' self-efficacy in making positive career decisions, (1978), 17.

United Nations. (2013). Economic Report on Africa 2013 Nigeria. International Journal of Developing Societies, 2013.

Yang, C. P., \& Lu, F. G. (2007). Indigenous and Cultural Psychology: Understanding People in Context. Pastoral Psychology, 56(1), 105-113. doi:10.1007/s11089-007-0090-1

Yorke, M. (2006). Employability in higher education: What it is - what it is not. In M. Yorke (Ed.), Leearning and Eemploaybility (Series One., pp. 1-24). The Higher Education Academy. Retrieved from http://www.heacademy.ac.uk/assets/was $\quad$ York - dete this soon/documents/ourwork/tla/employability/id116_employability_in_higher_education_336.pdf

Yorke, M., \& Knight, P. (2007). Evidence-informed pedagogy and the enhancement of student employability. Teaching in Higher Education, 12(2), 157-170.

Zimmerman, B., \& Schunk, D. (2001). Self-regulated learning and academic achievement: Theoretical perspectives. Mahwah, NJ: Lawrence Erlbaum Associates. 